\title{
Cytoprotection by Metallothionein Against Gastroduodenal Mucosal Injury Caused by Ethanol in Mice
}

\author{
Hirohisa Takano, Masahiko Satoh, Akinori Shimada, Masaru Sagai, \\ Toshikazu Yoshikawa, and Chiharu Tohyama
}

Regional Environment Division (HT, MS), and Environmental Health Sciences Division (MS, CT), National Institute for Environmental Studies, Tsukuba; First Department of Medicine (HT, TY), Kyoto Prefectural University of Medicine, Kyoto; and Department of Veterinary Pathology (AS), Tottori University, Tottori, Japan

SUMMARY: Metallothionein (MT) is a small, cysteine-rich protein that can act as a free radical scavenger at least in vitro. To test the hypothesis that MT participates in gastroduodenal cytoprotection, we studied sensitivity to gastroduodenal mucosal injury caused by ethanol in MT-null mice that have null mutations in MT-I and MT-II genes. MT-null mice and wild-type mice were orally treated with ethanol $(60 \%$ or $99.5 \%, 0.2 \mathrm{ml} /$ mouse). The macroscopic gastric lesion indices were significantly higher in MT-null mice than in wild-type mice 90 minutes after ethanol treatment. Histopathological examination in ethanol-treated MT-null mice showed vacuolar degeneration, necrosis of the epithelial cells, and hemorrhage throughout the tunica mucosa. Moreover, the duodenum also showed morphologic changes, including marked degeneration and coagulative necrosis of the entire villi, desquamation of the degenerated epithelial cells, and hemorrhage. In contrast, histopathologic changes were less prominent in the wild-type mice treated with ethanol. MT was not detected either in the stomach or duodenum of MT-null mice, whereas gastric and duodenal zinc contents were not significantly different between MT-null mice and wild-type mice. These results provide direct evidence that intrinsic MT plays a cytoprotective role in gastroduodenal mucosal injury caused by ethanol. (Lab Invest 2000, 80:371-377).

$M$ etallothionein (MT) is an evolutional, highly conserved, low molecular weight, thiol-rich protein that does not have aromatic amino acids, histidine, or disulfide bonds. MT was first identified as a cadmium (Cd)-binding protein and is found as a major zinc (Zn)-binding protein in various tissues. Because of its high sulfhydryl content, MT is thought to harbor broad functions in the regulation of $\mathrm{Zn}$ and copper (Cu) homeostasis, participation in the acute phase response, and detoxification of heavy metals (Hamer, 1986) and also to serve as a scavenger of oxygen-free radicals (Sato and Bremner, 1993). Previous studies have suggested that induction of MT by heavy metals such as $\mathrm{Zn}$ and $\mathrm{Cd}$ and cytokines induce cytoprotection against oxidant injury caused by ionizing radiation (Bakka et al, 1982; Basu and Lazo, 1990), doxorubicin (Basu and Lazo, 1990; Webber et al, 1988), hydrogen and organic peroxide (Schwartz et al, 1994), hyperoxia (Hart et al, 1990), carbon tetrachloride $\left(\mathrm{CCl}_{4}\right)$ (Schroeder and Cousins, 1990), and TNF (Leyshon-Sorland et al, 1993). These MT-inducing agents, however, are not specific for MT induction, and cytoprotection may therefore have been due to other effects of the agents.

Received November 2, 1999.

Address reprint requests to: Dr. M. Satoh, Environmental Health Sciences Division, National Institute for Environmental Studies, 16-2 Onogawa, Tsukuba, Ibaraki 305-0053, Japan. Fax: 8129850 2588; E-mail: masahiko@nies.go.jp
In addition, the role of MT constitutively expressed in virtually all cell types remains to be established.

There are four MT genes in the human and mouse. $M T-I$ and $M T-I l$ are expressed in all tissues and are considered most important in $\mathrm{Zn}$ and $\mathrm{Cu}$ homeostasis, detoxification of heavy metals, and scavenging of free radicals (Bremner and Beattie, 1990). MT-III and MT-IV isoforms exist in neural tissue and squamous epithelium, respectively (Masters et al, 1994b; Quaife et al, 1994). Recently, MT-null transgenic mice that are deficient in MT-I and MT-II were produced by the gene-targeting technique (Masters et al, 1994a;Michalska and Choo, 1993). Several studies have shown that MT-null mice have an increased sensitivity to oxidative stress induced by paraquat (Sato et al, 1996), ultraviolet (Hanada et al, 1998), or acetaminophen (Rofe et al, 1998; Zhang et al, 1999; Liu et al, 1999). In in vitro studies, primary cultured MT-null cells have also been found to be more sensitive to free radical-inducing substances such as paraquat and tert-butylhydroperoxide (Lazo et al, 1995; Zheng et al, 1996).

Alternatively, oxygen-free radicals are involved in the process of formation of gastric mucosal lesions that are induced by a variety of ulcerogenic stimuli such as ischemia-reperfusion (Perry et al, 1986), several kinds of stress (Ito and Guth, 1985; Yoshikawa et al, 1986; 1987), and ethanol (Pihan et al, 1987), and antioxidants can afford gastric cytoprotection. In ad- 
dition, it has been reported that intravenous administration of MT-II $(2.5 \mathrm{mg} / \mathrm{kg}, 1.0 \mathrm{mg} / \mathrm{kg}$, iv) suppresses the formation of water-immersion stress-induced and $\mathrm{HCl}-e$ thanol-induced gastric mucosal lesions in rats (Mimura et al, 1988). However, the role of constitutively expressed MT in gastric cytoprotection against ulcerogenic stimuli has not yet been elucidated. Our study was undertaken to examine the cytoprotective role of intrinsic MT in ethanol-induced gastroduodenal lesions using mice lacking MT-I and MT-II genes.

\section{Results}

\section{MT and Zinc Concentrations}

As shown in Table 1, MT protein in the stomach and duodenum was $14.9 \pm 6.5(\mu \mathrm{g} / \mathrm{g}$ tissue) and $6.59 \pm$ $1.0(\mu \mathrm{g} / \mathrm{g}$ tissue), respectively, in control wild-type mice. MT protein in the gastroduodenum was at the detection limit $(<0.2 \mu \mathrm{g} / \mathrm{g}$ tissue) in MT-null mice. Moreover, MT protein was not detected either in the liver or kidney of MT-null mice. Zn contents in the stomach, duodenum, liver, and kidney were not significantly different between MT-null mice and wildtype mice.

\section{Gastroduodenal Lesions}

As shown in Figure 1, the gastric lesion indices in MT-null mice and wild-type mice were $53.5 \pm 18.8$ $\mathrm{mm}$ and $10.4 \pm 5.3 \mathrm{~mm}$, respectively, at 90 minutes after $99.5 \%$ ethanol treatment. Those in MT-null mice and wild-type mice were $23.0 \pm 11.5 \mathrm{~mm}$ and $5.4 \pm$ $6.3 \mathrm{~mm}$, respectively, 90 minutes after $60 \%$ ethanol treatment. Ethanol-induced gastroduodenal injury was more severe in MT-null mice than in wild-type mice. The gastric mucosal injury in the lower portion of the stomach was dependent on the concentration of ethanol in both strains of mice. Compared with $99.5 \%$ ethanol-treated wild-type mice (Fig. 2B), MT-null mice treated in the same way showed a more severe degree of vacuolar degeneration and necrosis of the epithelial cells and hemorrhage throughout the tunica mucosa (Fig. 2D).

The duodenum in $99.5 \%$ ethanol-treated MT-null mice showed morphologic changes, including marked degeneration and coagulative necrosis of the entire villi (Fig. 3, E and F). Desquamation of the degenerated epithelial cells and hemorrhage were also observed in the lesions (Fig. 3, E and F). In comparison, his-

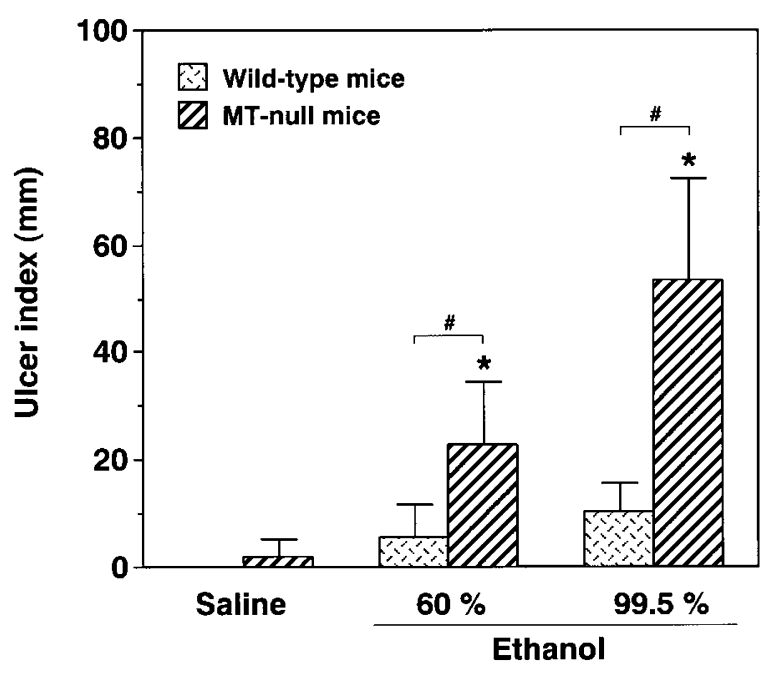

Figure 1.

Ethanol-induced gastric lesions in MT-null mice and wild-type mice. The values are mean \pm so seven mice. *Significantly different from the saline group $(p<$ $0.005) . \# p<0.01$.

topathologic changes were less prominent in the wildtype mice treated with ethanol (Fig. 3, B and C).

\section{Discussion}

This study demonstrated that oral administration of ethanol caused significantly more severe gastroduodenal mucosal injury in MT-null mice than in wild-type mice. MT-I and MT-II proteins were not detected in the stomach and duodenum of MT-null mice, whereas gastroduodenal $\mathrm{Zn}$ contents were not significantly different between MT-null mice and wild-type mice.

Oxygen-free radicals and lipid peroxidation have been reported to participate in the formation of gastric mucosal lesions caused by a variety of ulcerogenic stimuli, such as ischemia-reperfusion (Perry et al, 1986) and several kinds of stress (Ito and Guth, 1985; Yoshikawa et al, 1986; 1987). They have been implicated in the pathogenesis of ethanol-induced gastric mucosal injury as well (Pihan et al, 1987), because two enzymatic antioxidants, superoxide dismutase, and catalase reduced the gastric mucosal injury. In our study, oral administration of ethanol caused more severe gastroduodenal lesions in mice with a null mutation of MT-I and MT-II genes than in wild-type mice. To our knowledge, this would be the first published demonstration that intrinsic MT plays a cyto-

Table 1. MT and Zn Concentrations in Tissues of MT-Null Mice and Wild-Type Mice

\begin{tabular}{|c|c|c|c|c|}
\hline \multirow[b]{2}{*}{ Tissues } & \multicolumn{2}{|c|}{ MT ( $\mu \mathrm{g} / \mathrm{g}$ tissue $)$} & \multicolumn{2}{|c|}{$\mathrm{Zn}(\mu \mathrm{g} / \mathrm{g}$ tissue $)$} \\
\hline & Wild-type & MT-null & Wild-type & MT-null \\
\hline Stomach & $14.9 \pm 6.5$ & $<0.2$ & $12.5 \pm 1.3$ & $10.8 \pm 2.2$ \\
\hline Duodenum & $6.59 \pm 1.01$ & $<0.2$ & $12.4 \pm 1.5$ & $11.2 \pm 2.4$ \\
\hline Liver & $15.8 \pm 5.0$ & $<0.2$ & $21.2 \pm 2.6$ & $18.8 \pm 3.4$ \\
\hline Kidney & $7.16 \pm 2.51$ & $<0.2$ & $16.4 \pm 2.5$ & $14.6 \pm 4.1$ \\
\hline
\end{tabular}

The values are mean \pm SD for five mice. 

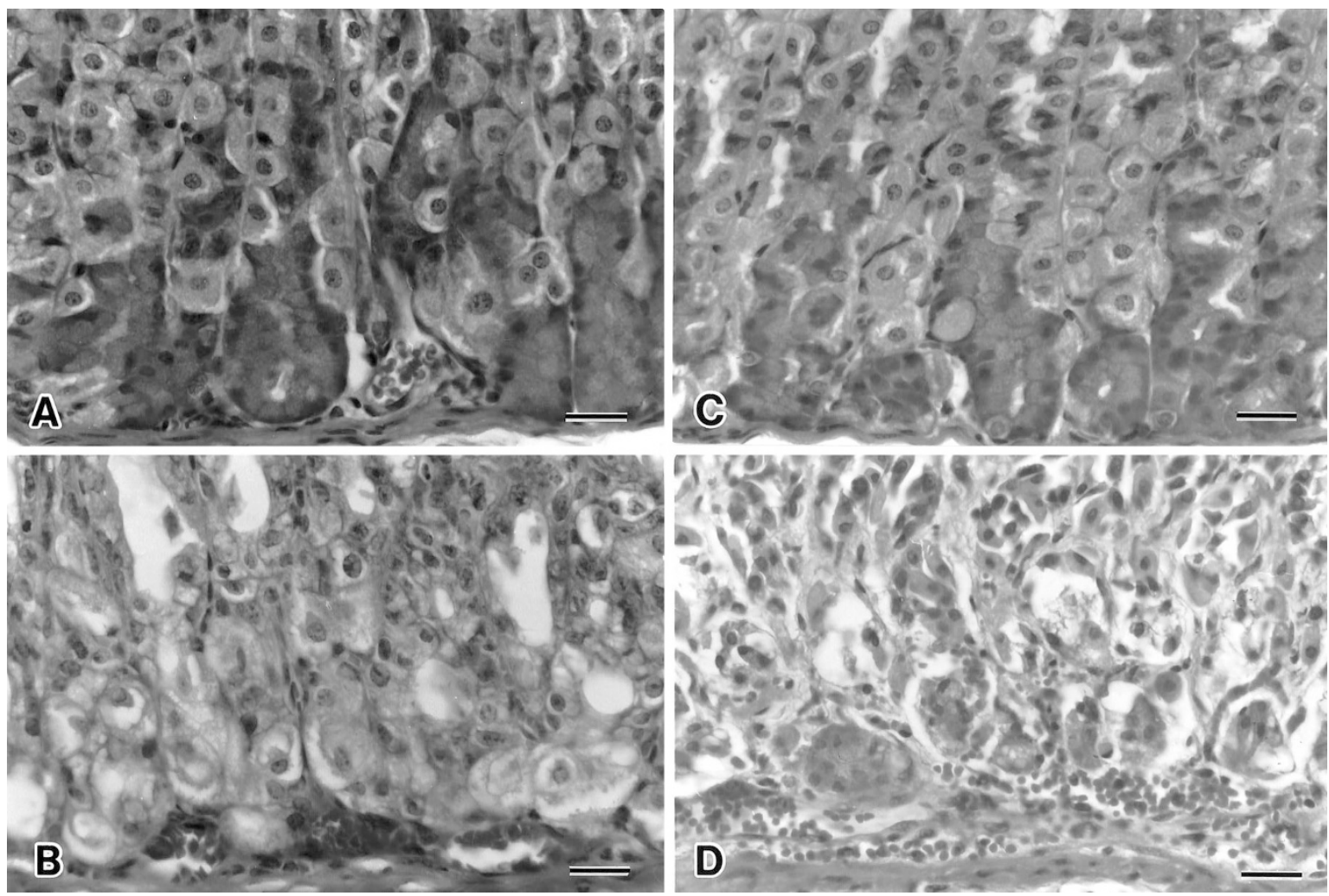

\section{Figure 2.}

Histopathological changes in the gastric mucosa of MT-null mice and wild-type mice 90 minutes after the $99.5 \%$ ethanol injection. $A$, Untreated wild-type mice; $B$, 99.5\%-ethanol-treated wild-type mice; $C$, Untreated MT-null mice; and D, 99.5\%-ethanol-treated MT-null mice. Bar $=20 \mu \mathrm{m}$.

protective role against acute gastroduodenal lesions induced by ethanol and that it may act as an antioxidant in the gastroduodenal mucosa in vivo.

MT is a ubiquitous protein that forms high affinity complexes with an assortment of heavy metals, including mercury, $\mathrm{Cd}$, silver, and biologically essential metals like $\mathrm{Zn}$ and $\mathrm{Cu}$ (Hamer, 1986). It is generally agreed that MT plays a protective role against heavy metal toxicity and a regulatory role in $\mathrm{Zn}$ and $\mathrm{Cu}$ homeostasis in living organisms. However, it is not likely that these two roles are the exclusive functions of MT for two reasons. First, heavy metals such as $\mathrm{Cd}$ and mercury are not always present in the environment at high concentrations. Second, MT can be induced by nonmetal inducers, such as cytokines and drugs. Cytokines, such as IL-1, IL-6, and TNF- $\alpha$, are effective inducers of MT under experimental and disease conditions like partial hepatectomy, lipopolysaccharide administration, and inflammation. Drugs such as cisplatin, acetaminophen, indomethacin cephaloridine, and adriamycin, which are known to generate oxygen-free radicals, are responsible for MT induction in various tissues as well (Basu and Lazo, 1990; Karin, 1985). Moreover, the rich cysteine content and the ubiquitous cellular and phylogenic distribution of MT imply other important physiological functions.

There is some circumstantial evidence for the role of MT as an antioxidant. First, various physical and chemical stimuli associated with oxidative stress increase MT gene expression. X-irradiation (Koropatnick et al, 1989), hyperoxia (Veness-Meehan et al, 1991), and restraint (Bauman et al, 1991) result in tissuespecific increases in oxygen-free radicals and mRNA expression for MT. Xenobiotics such as paraquat (Hidalgo et al, 1988) and $\mathrm{CCl}_{4}$ (De et al, 1990) and anticancer drugs such as doxorubicin (Basu and Lazo, 1990; Bauman et al, 1991) have similar effects in vivo. These stimuli, however, can cause an inflammatory response, including the production of cytokines, such as interleukin-1, interleukin-6, TNF- $\alpha$, and interferon- $\gamma$, which can increase MT gene expression (De et al, 1990; Hamer, 1986; Karin, 1985; Schroeder and Cousins, 1990). Thus, it remains controversial whether oxygen-free radicals per se or secondary cytokines affect MT expression in vivo. Second, MT induction with heavy metals or cytokines reduces cell sensitivity to oxidative stresses caused by irradiation (Bakka et al, 1982; Basu and Lazo, 1990), peroxides (Schwartz et al, 1994), hyperoxia (Hart et al, 1990), $\mathrm{CCl}_{4}$ (Schroeder and Cousins, 1990), and TNF- $\alpha$ (Leyshon-Sorland et al, 1993). However, heavy metals and cytokines are promiscuous transcriptional activators, and $\mathrm{Cd}$ or $\mathrm{Zn}$ pretreatment can produce an $\mathrm{H}_{2} \mathrm{O}_{2}$-resistant cell as a result of activating non-MT antioxidants (Chubatsu et al, 1992).

The generation of MT-null mice provides a more direct and simple experimental model with which the role of MT as a member of the intracellular antioxidant network can be examined (Hanada et al, 1998; Lazo et al, 1995; Liu et al, 1999; Rofe et al, 1998; Sato et al, 

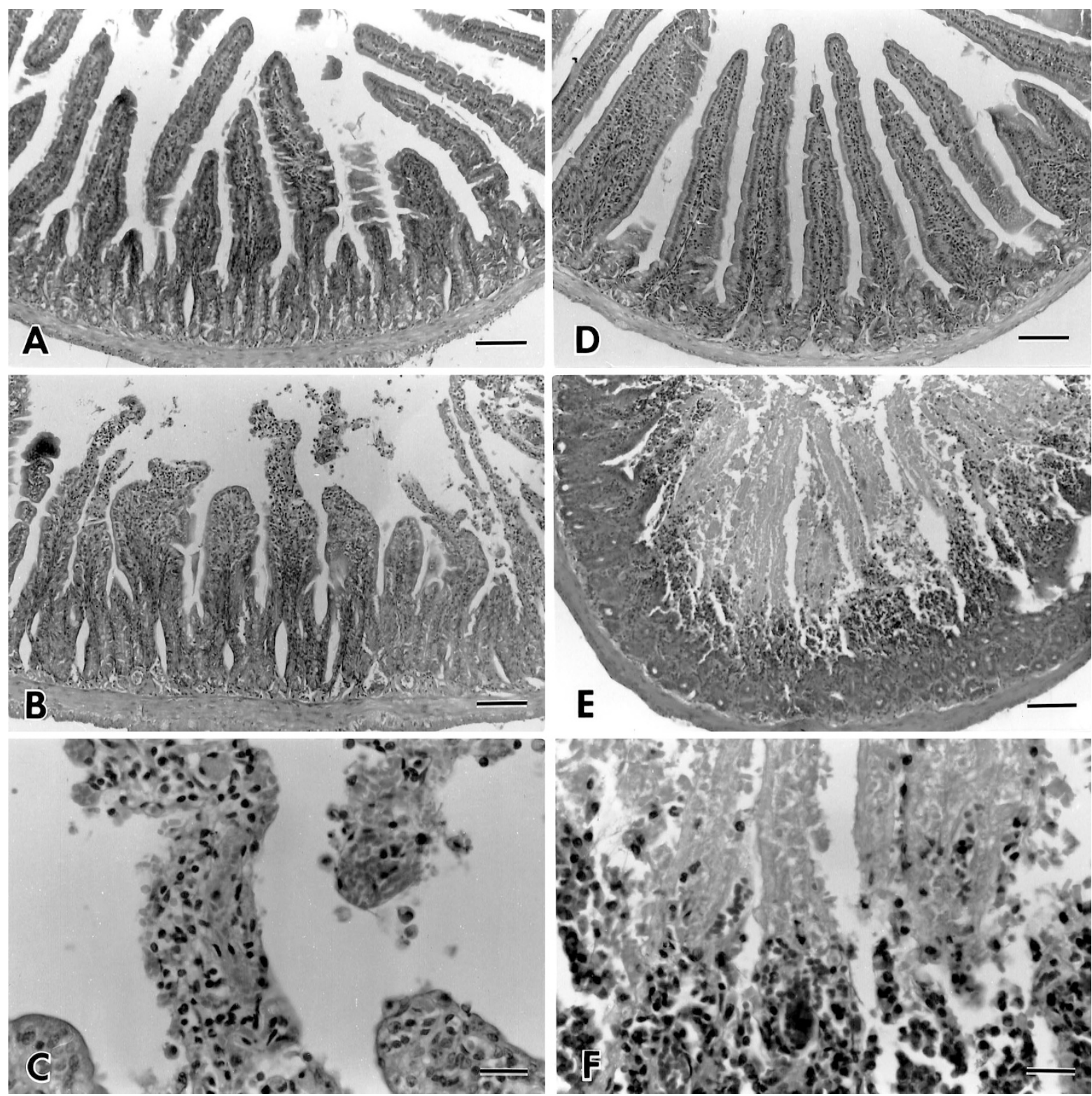

\section{Figure 3.}

Histopathological changes in the duodenal mucosa of MT-null mice and wild-type mice 90 minutes after the $99.5 \%$ ethanol injection. $A$, Untreated wild-type mice $(B a r=80 \mu \mathrm{m}) ; B, 99.5 \%$-ethanol-treated wild-type mice $(B a r=80 \mu \mathrm{m}) ; C, 99.5 \%$-ethanol-treated wild-type mice $(B a r=20 \mu \mathrm{m}) ; D$, Untreated MT-null mice $(B a r=$ $80 \mu \mathrm{m}) ; E, 99.5 \%$-ethanol-treated MT-null mice $(B a r=80 \mu \mathrm{m}) ;$ and $F, 99.5 \%$-ethanol-treated MT-null mice $(B a r=20 \mu \mathrm{m})$.

1996; Zhang et al, 1999; Zheng et al, 1996). Lazo et al (1995) have shown that embryonic cells from transgenic mice with target disruption of MT-I and MT-II genes expressed no detectable MT either constitutively or after treatment with $\mathrm{Cd}$, in contrast to cultured cells that were wild-type or heterozygous for the loss of the MT genes. MT-null cells were most sensitive to the cytotoxic effects of $\mathrm{Cd}$, a membrane-permeable oxidant tert-butylhydroperoxide, and of a redoxcycling toxin, paraquat. No marked differences have been seen among the wild-type, heterozygous, or MT-null cells in glutathione levels or in the activity of either $\mathrm{Cu}, \mathrm{Zn}$-superoxide dismutase, glutathione peroxidase, or catalase. Glutathione levels in the stomach were not significantly different between MT-null mice and wild-type mice in our experiment (data not shown). Some reports have recently shown that MTnull mice are more susceptible than wild-type mice to acetaminophen hepatotoxicity caused by $\mathrm{N}$-acetyl-pbenzoquinone imine, a reactive intermediate formed when acetaminophen is oxidized via the cytochrome P450 pathway, and that MT has an hepatoprotective, presumably antioxidant function (Liu et al, 1999); Rofe et al, 1998; Zhang et al, 1999). In addition, Kang et al (1997) have reported that transgenic mice in which MT-II was overexpressed in the heart exhibited a significant resistance to in vivo doxorubicin-induced cardiac toxicity as compared with normal controls. Doxorubicin has been suggested to increase the formation of reactive oxygen species in the heart, result- 
ing in lipid peroxidation and consequently causing doxorubicin-caused cardiomyopathy (Olson et al, 1988). Antioxidants such as $\mathrm{N}$-acetylcysteine (Powell and McCay, 1988), vitamin E, superoxide dismutase (Hida et al, 1995), and catalase (Myers et al, 1977) decreased the severity of doxorubicin-induced oxidative damage. Judging from these reports and the results of our study, MT is thought to play a cytoprotective role against oxidative injury in various types of cells and organs, including the gastrointestinal tract, liver, and heart and to function as an antioxidant. In addition, constitutive MT levels affect the sensitivity of the mammalian gastrointestinal tract to oxidative stress. A striking finding was that starvation of MT-null mice for 48 hours caused mild gastric mucosal injury without ethanol treatment. It is possible that starvation may be a stress and subsequently an ulcerogenic stimulus in MT-null mice.

The mechanism by which MT acts as an antioxidant is unclear, although it can scavenge phenoxyl radicals in vivo as determined by electron spin resonance (Schwartz et al, 1994). MT itself can act as a scavenger for hydroxyl radicals and superoxide anion in vitro (Sato and Bremner, 1993). The cysteine residues of MT might serve as an expendable target for reactive oxygen species. Alternatively, the primary determinant of MT protection is the release of its associated metal, $\mathrm{Zn}$, and the subsequent uptake of $\mathrm{Zn}$ by the membrane (Thomas et al, 1986), because $\mathrm{Zn}$ protects against lipid peroxidation and thereby stabilizes membranes (Chavapil et al, 1972). Another possibility is that MT chelates iron or otherwise mediates its conversion into a form that is not active as a Fenton reactant. The formation of an iron-MT complex in vitro has been described elsewhere (Good and Vasak, 1986).

Although $\mathrm{Zn}$ is known as an important defense element in the stomach (Cho et al, 1987), Zn contents in the stomach were not significantly different between wild-type mice and MT-null mice in our experiments. Because reactive oxygen species, however, could exchange or replace Zn from MT (Maret, 1994), it is possible that the released $\mathrm{Zn}$ may stabilize the biological membranes (Chavapil et al, 1972; Thomas et al, 1986) or act as an antioxidant (Bray and Bettger, 1990).

In conclusion, intrinsic MT participates in gastroduodenal cytoprotection against ethanol, presumably as an antioxidant. MT induction may have therapeutic efficacy for gastroduodenal injury induced by oxidative stress.

\section{Materials and Methods}

\section{Animals}

MT-null mice whose MT-I and MT-Il genes had null mutations and wild-type mice were kindly provided by Dr. A. Choo (Murdoch Institute for Research into Birth Defects, Royal Children's Hospital, Parkville, Australia) (Michalska and Choo, 1993). Both kinds of mice were originally from a mixed genetic background of OLA129 and C57BL6 strains. These mice were routinely bred in the vivarium of the National Institute for Environmental Studies (Tsukuba, Japan), reproducing normally and displaying no overt abnormality in physical state and behavior.

MT-null mice and wild-type mice were housed in cages in ventilated animal rooms with controlled temperature $\left(23 \pm 1^{\circ} \mathrm{C}\right)$ and relative humidity $(55 \pm 10 \%)$ and a 12-hour light-dark cycle. They were maintained on standard laboratory chow and tap water ad libitum and received humane care throughout the experiment according to the guidelines of the National Institute for Environmental Studies.

\section{Treatment}

Eight-week-old male MT-null mice and wild-type mice were randomized into control and experimental groups, respectively. The groups of mice $(5$ mice in each group) were deprived of food for 48 hours in stainless steel cages with wire mesh floors to prevent coprophagy but allowed free access to water up to the commencement of the experiments. Animals were orally treated with ethanol $(60 \%$ or $99.5 \%, 0.2 \mathrm{ml} /$ mouse). Ninety minutes after ethanol treatment, the animals were killed with exsanguination under ether anesthesia. The stomach and duodenum were removed to evaluate ethanol-induced gastroduodenal lesions. In previous reports using $90 \%$ or absolute ethanol, mucosal injury was evaluated 60 minutes after ethanol administration (Bhandare et al, 1990; Melchiorri et al, 1997; Tsuji et al, 1993). Because we used $60 \%$ ethanol as well as $99.5 \%$ ethanol, a longer duration (90 minutes) than that used in the previous reports was selected before we observed the tissues for mucosal injury.

\section{Histochemical Staining}

To perform histochemical evaluation of the gastroduodenal lesions, the stomach and duodenum were cut in half along the lesser curvature. One piece was fixed in $10 \%$ buffered formalin $(\mathrm{pH} 7.4)$ and embedded in paraffin. Sections of $5 \mu \mathrm{m}$ thickness were routinely processed with hematoxylin and eosin stain.

\section{Analysis}

The stomach was opened along the greater curvature. The length of the gastric mucosal lesions was measured in each mouse. The sum of the lesion length per stomach was used as a lesion index. The amount of MT and $\mathrm{Zn}$ in tissues was determined by using radioimmunoassay (Tohyama and Shaikh, 1981) as modified by Nishimura et al (1989) and inductively-coupled plasma emission spectrometry (ICP; model ICAP-750, Nippon-Jarrel-Ash, Tokyo, Japan) after digestion with a concentrated acid mixture $\left(\mathrm{HNO}_{3}: \mathrm{HClO}_{4}=1: 3\right.$ $[\mathrm{v} / \mathrm{v}])$.

\section{Statistics}

The data are presented as the means \pm SD. Differences in the lesion index and in the contents of MT 
and $\mathrm{Zn}$ among groups of mice were determined using ANOVA (Statview; Abacus Concepts, Inc., Berkeley, California). If differences among groups were significant $(p<0.05)$, Fisher's protected least significant difference test or Scheffe's F test was used to distinguish between pairs of groups.

\section{References}

Bakka A, Jonsen AS, Endresen L, and Rugstad HE (1982). Radioresistance in cells with high content of metallothionein. Experientia 38:381-383.

Basu A and Lazo JS (1990). A hypothesis regarding the protective role of metallothioneins against the toxicity of DNA interactive anticancer drugs. Toxicol Lett 50:123-135.

Bauman JW, Liu L, Liu YP, and Klaassen CD (1991). Increase in metallothionein produced by chemicals that induce oxidative stress. Toxicol Appl Pharmacol 110:347-354.

Bhandare P, Diniz-D'Souza R, Mainker A, and Dhume V (1990). Protective effect of propranolol on ethanol-induced gastric lesions in mice. Eur J Pharmacol 19 1:167-172.

Bray T and Bettger WJ (1990). The physiological role of zinc as an antioxidant. Free Rad Biol Med 8:281-291.

Bremner I and Beattie JH (1990). Metallothionein and the trace minerals. Annu Rev Nutr 10:63-83.

Chavapil M, Ryam JN, and Zukoshi CF (1972). Effect of zinc on lipid peroxidation in liver microsomes and mitochondria. Proc Soc Exp Biol Med 141:150-153.

Cho CH, Fong LYY, Ma PCC, and Ogle CW (1987). Zinc deficiency: Its role in gastric secretion and stress-induced gastric ulceration in rats. Pharmac Biochem Behavior 26: 293-297.

Chubatsu LS, Gennari M, and Meneghini R (1992). Glutathione is the antioxidant responsible for resistance to oxidative stress in V79 Chinese hamster fibroblasts rendered resistant to cadmium. Chem Biol Interact 82:99-110.

De SK, McMaster MT, and Andrews GK (1990). Endotoxin induction of murine metallothionein gene expression. J Biol Chem 265:15267-15274.

Good M and Vasak M (1986). Spectroscopic properties of the cobalt (II)-substituted alpha-fragment of rabbit liver metallothionein. Biochemistry 25:8353-8356.

Hamer DH (1986). Metallothionein. Ann Rev Biochem 55: 913-951.

Hanada K, Sawamura D, Hashimoto I, Kida K, and Naganuma A (1998). Epidermal proliferation of the skin in metallothionein-null mice. J Invest Dermatol 110:259-262.

Hart BA, Voss GW, Shatos MA, and Doherty J (1990). Cross-tolerance to hyperoxia following cadmium aerosol pretreatment. Toxicol Appl Pharmacol 103:255-270.

Hida H, Coudray C, Calop J, and Favier A (1995). Effect of antioxidants on adriamycin-induced microsomal lipid peroxidation. Biol Trace Elem Res 47:111-116.

Hidalgo J, Campany L, Borras M, Garvey JS, and Armario A (1988). Metallothionein response to stress in rats: Role in free radical scavenging. Am J Physiol 255:E518-E524.

Ito $\mathrm{M}$ and Guth $\mathrm{PH}$ (1985). Role of oxygen-derived free radicals in hemorrhagic shock-induced gastric lesions in the rat. Gastroenterology 88:1162-1167.
Kang YJ, Chen Y, Yu A, Voss-McCowan M, and Epstein PN (1997). Overexpression of metallothionein in the heart of transgenic mice suppresses doxorubicin cardiotoxicity. J Clin Invest 100:1501-1506.

Karin M (1985). Metallothioneins: Proteins in search of function. Cell 41:9-10.

Koropatnick J, Leibbrandt M, and Cherian MG (1989). Organspecific metallothionein induction in mice by $\mathrm{X}$-irradiation. Radiat Res 119:356-365.

Lazo JS, Kondo Y, Dellapiazza D, Michalska AE, Choo KHA, and Pitt BR (1995). Enhanced sensitivity to oxidative stress in cultured embryonic cells from transgenic mice deficient in metallothionein-I and -II genes. J Biol Chem 270:5506-5510.

Leyshon-Sorland K, Morkrid L, and Rugstad HE (1993). Metallothionein: A protein conferring resistance in vitro to tumor necrosis factor. Cancer Res 53:4874-4880.

Liu L, Liu Y, Hartley D, Klaassen CD, Shehin-Johnson ST, Lucas A, and Cohen SD (1999). Metallothionein-I/II knockout mice are sensitive to acetaminophen-induced hepatotoxicity. J Pharmacol Exp Ther 289:580-586.

Maret W (1994). Oxidative metal release from metallothionein via zinc-thiol/disulfide interchange. Proc Natl Acad Sci USA 91:237-241.

Masters BA, Kelly EJ, Quaffe CJ, Brinster RL, and Palmiter RD (1994a). Targetting disruption of metallothionein-I and -II genes increases sensitivity to cadmium. Proc Natl Acad Sci USA 91:584-588.

Masters BA, Quaife CJ, Kelly EJ, Froelick GJ, Zambrowicz BP, Brinster RL, and Palmiter RD (1994b). Metallothionein-III is expressed in neurons that sequester zinc in synaptic vessels. J Neurosci 14:5844-5857.

Melchiorri D, Sewerynek E, Reiter RJ, Ortiz GG, Poeggeler B, and Nistico G (1997). Suppressive effect of melatonin administration on ethanol-induced gastroduodenal injury in rats in vivo. Br J Pharmacol 121:264-270.

Michalska A and Choo KHA (1993). Targeting and germ-line transmission of a null mutation at the metallothionein-I and -II loci in mice. Proc Natl Acad Sci USA 90:8088-8092.

Mimura T, Tsujikawa K, Yasuda N, Nakajima H, Haruyama M, Ohmura T, and Okabe M (1988). Suppression of gastric ulcer induced by stress and $\mathrm{HCl}$-ethanol by intravenously administered metallothionein-II. Biochem Biophys Res Commun 151:725-729.

Myers CE, McGuire WP, Liss RH, Grotzinger K, and Young RC (1977). Adriamycin: The role of lipid peroxidation in cardiac toxicity and tumor response. Science 1977:165-167.

Nishimura N, Nishimura H, and Tohyama C (1989). Localization of metallothionein in female reproductive organs of rat and guinea pig. J Histochem Cytochem 37:1601-1607.

Olson RD, Boerth RC, Gerber JG, and Nies AS (1988). Mechanism of adriamycin cardiotoxicity. Evidence for oxidative stress. Life Science 29:1393-1401.

Perry MA, Wadhwa S, Parks DA, Pickard W, and Granger DN (1986). Role of oxygen radicals in ischemia-induced lesions in the cat stomach. Gastroenterology 90:362-367.

Pihan G, Regillo C, and Szabo S (1987). Free radicals and lipid peroxidation in ethanol- or aspirin-induced gastric mucosal injury. Digest Dis Sci 32:1395-1401. 
Powell SR and McCay PB (1988). Inhibition of doxorubicininitiated membrane damage by $\mathrm{N}$-acetylcysteine: Possible mediation by a thiol-dependent cytosolic inhibitor of lipid peroxidation. Toxicol Appl Pharmacol 96:175-184.

Quaife CJ, Findlay SD, Erickson JC, Froelick GJ, Kelly EJ, Zambrowicz BP, and Palmiter RD (1994). Induction of a new metallothionein isoform (MT-IV) occurs during differentiation of stratified squamous epithelia. Biochemistry 33:72507259.

Rofe AM, Barry EF, Shelton TL, Philcox JC, and Coyle P (1998). Paracetamol hepatotoxicity in metallothionein-null mice. Toxicology 125:131-140.

Sato M and Bremner I (1993). Oxygen-free radicals and metallothionein. Free Radical Biol Med 14:325-337.

Sato M, Apostolova MD, Hamaya M, Yamaki J, Choo KHA, Michalska AE, Kodama N, and Tohyama C (1996). Susceptibility of metallothionein-null mice to paraquat. Environ Toxicol Pharmacol 1:221-225.

Schroeder JJ and Cousins RJ (1990). Interleukin 6 regulates metallothionein gene expression and zinc metabolism in hepatocyte monolayer cultures. Proc Natl Acad Sci USA 87:3137-3141.

Schwartz MA, Lazo JS, Yalowich JC, Reynolds I, Kagan VE, Tyurin V, Kim YM, Watkins SC, and Pitt BR (1994). Cytoplasmic metallothionein overexpression protects NIH 3T3 cells from tert-butylhydroperoxide toxicity. J Biol Chem 269: 15238-15243.

Thomas JP, Bachowski GL, and Girotti AW (1986). Inhibition of cell membrane lipid peroxidation by cadmium-and zincmetallothionein. Biochim Biophys Acta 884:48-461.
Tohyama C and Shaikh ZA (1981). Metallothionein in plasma and urine of cadmium-exposed rats determined by a singleantibody radioimmunoassay. Fund Appl Toxicol 1:1-7.

Tsuji K, Uehara A, Santos SB, and Namiki M (1993). Endotoxin protects the gastric mucosa against ulcerogenic stimuli. Biochem Biophys Res Commun 197:1326-1333.

Veness-Meehan KA, Cheng ERY, Mercier CE, Blixt SL, Johnston CJ, Watkins RH, and Horowitz S (1991). Cellspecific alterations in expression of hyperoxia-induced $\mathrm{mR}$ NAs of lung. Am J Respir Cell Mol Biol 5:516-521.

Webber MM, Rehman SMM, and James GT (1988). Metallothionein induction and deinduction in human prostatic carcinoma cells: Relationship with resistance and sensitivity to adriamycin. Cancer Res 48:4503-4508.

Yoshikawa T, Miyagawa H, Yoshida N, Sugini S, and Kondo $M$ (1986). Increase in lipid peroxidation in rat gastric mucosal lesions induced by water-immersion restraint stress. J Clin Biochem Nutr 1:271-277.

Yoshikawa T, Yoshida N, Miyagawa H, Takemura T, Tanigawa T, Sugino S, and Kondo M (1987). Role of lipid peroxidation in gastric mucosal lesions induced by burn shock in rats. J Clin Biochem Nutr 2:163-170.

Zhang B, Satoh M, and Tohyama C (1999). A protective role for metallothionein in acetaminophen-caused liver toxicity via oxidative stress. J Health Sci 45:15-19.

Zheng H, Liu J, Liu Y, and Klaassen CD (1996). Hepatocytes from metallothionein-I and -II knock-out mice are sensitive to cadmium- and tert-butylhydroperoxide-induced cytotoxicity. Toxicol Lett 87:139-145. 